\title{
Cerebral Cortical Changes in Adult Albino Rats Under the Effect of Tramadol and its Withdrawal: Histological and Morphometric
} Original Study Article

\author{
Shaimaa M. Motawea, Rabab M. Amer, Doaa A. Haibaa and Magdy S. Mostafa
}

Anatomy Department, Faculty of Medicine, Tanta University, Egypt

\begin{abstract}
Introduction: Analgesics are the most commonly used drugs worldwide. Tramadol hydrochloride (opioid) is a synthetic centrally acting analgesic agent used for treating moderate to severe pain with less side effects than traditional opioid medications.

Aim of the Work: To study the histological and morphometric changes of the cerebral cortex in adult albino rats after tramadol hydrochloride administration and the effect of its withdrawal.

Materials and Methods: Twenty four adult albino rats were used regardless sex, divided into 3 groups: a control group: consisted of 8 rats and were furtherly subdivided into two equal subgroups: a subgroup, rats were kept without any medication for 4 weeks and another where rats received saline daily by intraperitoneal injection for 4 weeks. Tramadol Group included 8 rats received the therapeutic dose of tramadol intraperitoneally for 4 weeks. Withdrawal group included 8 rats received the same dose as tramadol group then kept for 4 weeks later without treatment to study the effect of its withdrawal. The obtained specimens were examined by both light and electron microscopy.

Results: The control group showed the normal histological picture of the cerebral cortex. The Tramadol group revealed loss of organization of cerebral cortex layers, some pyramidal and granular cells with pyknotic nuclei and surrounded by haloes. Astrocytes showed hypertrophy of their cell bodies with increased thickening of their processes. Ultrastructurally, the pyramidal cells showed heterochromatic nuclei with marked indentations of their membranes and the myelinated axons showed splitting of myelin sheaths with swollen mitochondria in their axoplasm. Withdrawal group showed evidence of improvement as compared to the tramadol group.

Conclusion: Opioid analgesics (Tramadol hydrochloride) when the therapeutic dose is used for a long time led to marked damaging effect on the cerebral cortex, However, its withdrawal resulted in improvement to a lesser extent of their damaging effects.
\end{abstract}

Received: 26 June 2019, Accepted: 05 October 2019

Key Words: Cerebral, cortex, rats, tramadol.

Corresponding Author: Rabab M. Amer, MD, Anatomy Department, Faculty of Medicine, Tanta University, Egypt, Tel.: +20 1002775049, E-mail: rabab.amer@med.tanta.edu.eg

ISSN: 1110-0559, Vol. 43, No.2

\section{INTRODUCTION}

Pain is a vital physiological sign of injury or tissue damage. It is an unpleasant sensory condition but is essential for human survival. To relief pain there are two main types of analgesics, narcotic (opioid) and non-narcotic (non-opioid) analgesics. Opioid analgesics relieve pain by acting directly on the central nervous system. They are much stronger and used for severe pain not responding to non-narcotic analgesics $^{[1,2]}$.

Opiates are used routinely and effectively for the treatment of acute severe pain. They also reduce anxiety and produce mild sedation. The problem in their use is that they commonly cause abuse and addiction. In addition, high doses of potent opiates may cause marked respiratory depression and even death ${ }^{[3,4]}$.

Tramadol is the most widely used opioid analgesic nowadays. It is a synthetic analogue of codeine having central effects. It has the advantage of less respiratory and cardiovascular side effects if compared to other traditional opioids like morphine, pethidine, and oxycodone. Tramadol is currently available as tablets, oral drops, solution for injection, and suppository ${ }^{[5-7]}$.

Tramadol exists as a (1:1) mixture of the $(+)$ and (-)-enantiomers. Enantiomers (pair of stereoisomers that are mirror images of one another) are non-superimposable on one another. It has two different mechanisms of action. The first one is noradrenergic and serotonergic (non- opioid) mechanism while the second is opioid mechanism ${ }^{[8,9]}$.

The use of tramadol mixture as analgesic is better than the use of $(+)$ or $(-)$ form alone, as the tramadol mixture provides similar analgesic effect as its $(+)$ form but is better tolerated than it and more potent as analgesic than its (-) form ${ }^{[10-12]}$.

However, recent studies showed that the use of tramadol alone does not always provide enough analgesia, as it has no 
significant effect in relieving chronic non-specific low back pain, moreover, tramadol monotherapy does not usually provide enough analgesia in severe pain for more than three months ${ }^{[13,14]}$.

Adverse effects of tramadol depend on the dose and the mode of administration, as intravenous and intraperitoneal routs are more harmful. The therapeutic dose of tramadol can induce nausea, vomiting, increased sweating, drowsiness and headache. Experimental studies showed that oral or intraperitoneal tramadol administration induced rat brain alterations, including brain congestion and edema and its chronic use for more than 3 months in increasing doses was also associated with different neuronal degenerations ${ }^{[15-17]}$.

Prolonged use of tramadol with high doses exceeding the maximum recommended dose of $400 \mathrm{mg}$ per day will cause physical dependence and a withdrawal syndrome. The withdrawal symptoms include numbness, tingling and psychic manifestations as hallucinations, panic attacks, and confusion. Tramadol withdrawal symptoms appear 12-20 hours after the last dose and may last for seven days or more $^{[18-20]}$

As tramadol has recorded adverse effects on the brain, this work aimed to study the histological and morphometric changes of the cerebral cortex of the frontal lobe in adult albino rats after a long period administration of the therapeutic dose of tramadol hydrochloride (opioids) and the effect of its withdrawal.

\section{MATERIALS AND METHODS}

\section{2-1. Experimental Animals}

In this study, 24 adult male albino rats of average weight (150-200 grams) aging 3-4 months were used and maintained under specific clean conditions in the Animal House of Faculty of Medicine, Tanta University. The rats were housed in plastic cages with free access to water and food. All the steps of the experiment were carried out according to the rules of the ethical committee on animal's experiments of Tanta University.

\section{2-2. Drugs}

\section{Tramadol Hydrochloride}

Tramal capsules were obtained from Minapharm, Hilupollis, Cairo, Egypt. Each capsule contains $50 \mathrm{mg}$ tramadol hydrochloride powder. The powder of each capsule was dissolved in $2.5 \mathrm{ml}$ saline. Each $1 \mathrm{ml}$ of the formed solution contained $20 \mathrm{mg}$ of tramadol. Each rat received 0.5 $\mathrm{ml}$ of the formed solution $(50 \mathrm{mg} / \mathrm{kg} / \text { day })^{[15 \& 21]}$.

\section{2-3. The Experimental Design}

The animals were randomly allocated into control and experimental groups:

1- Control group I: This group consisted of 8 rats and were furtherly subdivided into two equal subgroups:

Subgroup Ia (negative control): The rats of this subgroup were kept without any medication for 4 weeks.
Subgroup Ib (vehicle control): The rats of this subgroup received $0.5 \mathrm{ml}$ saline daily by intraperitoneal injection for 4 weeks.

2- Tramadol Group (group II): It included 8 rats. Each rat received the therapeutic dose $(50 \mathrm{mg} / \mathrm{Kg} /$ day $)$ of tramadol intraperitoneally for 4 weeks ${ }^{[21]}$.

3- Tramadol Withdrawal Group (group III): It included 8 rats. Each rat received the same dose as tramadol group then kept for another 4 weeks without treatment to study the effect of its withdrawal.

At the optimum time of each group, all animals were sacrificed using an appropriate dose of ether, then the vault of the skull of each rat was removed exposing the two cerebral hemispheres, after that, specimens were taken from the cerebral cortex of the frontal lobe of both cerebral hemispheres of each rat.

\section{2-4. Light microscopic study}

Specimens were fixed in 10\% neutral buffered formalin and then prepared for:

\section{1- Hematoxylin and Eosin stain}

H\&E stain was used to study the general histological structure of rat's cerebral cortex in all groups ${ }^{[22]}$.

\section{2- Glial fibrillary acidic protein (GFAP)} immunohistochemistry

It was used to study the astrocytes. Its method was as follows; tissue sections were deparaffinized and dipped in phosphate buffered saline (PBS, pH 7.4) (Sigma Chemical Co.) and then kept in cold methanol (BDH Laboratory Supplies, UK) at $-20{ }^{\circ} \mathrm{C}$ for $4 \mathrm{~min}$. Then they were treated for 30 min with $3 \%$ (dilution from $30 \%$ ) $\mathrm{H} 2 \mathrm{O} 2$ and washed with PBS before applying the primary antibody. The primary antibody rabbit anti-GFAP was diluted 1:20 in PBS (Sigma Chemical Co.) and added, then the secondary antibody biotin anti-rabbit, which was diluted 1:20 in PBS containing 1\% bovine serum albumin (BSA; Sigma Chemical Co.) for 30 min. and added. Slides were then washed three times in PBS and treated with diaminobenzidene tetrahydrochloride (BioRad Laboratories, Canada) for $30 \mathrm{sec}$. Mayer's Haematoxylin was used as a counter nuclear stain and finally, the slides were washed in distilled water, dried, and placed in xylene for 5 min and mounted with a mixture of distyrene, a plasticizer and xylene (DPX) to preserve stain. GFAP immunoreactivity was indicated by brown coloration of the cytoplasm in the astrocytes. External positive tissue control was brain, cerebellum and striatum. Negative control sections were prepared by excluding the primary antibody ${ }^{[23]}$.

\section{2-5. Transmission electron microscopic study}

Specimens were divided by a sharp glass knife into small pieces ( $1 \mathrm{~mm} 3$ in size), then were fixed by immersion in $2.5 \%$ phosphate buffered glutaraldehyde, processed, and then prepared for semithin sections stained with toluidine blue stain and ultrathin sections stained with uranyl acetate and lead citrate to be examined by transmission electron microscope $\mathrm{e}^{[24,25]}$. 


\section{Morphometric study}

Counting of GFAP +ve astrocytes in all groups to determine the mean number of astrocytes in sections of the cerebral cortex of the frontal lobe of adult male albino rats stained with anti GFAP stain ${ }^{[26]}$. Cells were counted in the external pyramidal layer zone in 10 different fields at magnification of 400 /slide in each group using image $\mathrm{J}$ software program and photographed by Leica Qwin 500 at the Pathology Department, National Research Centre, Cairo. (Figure 1)

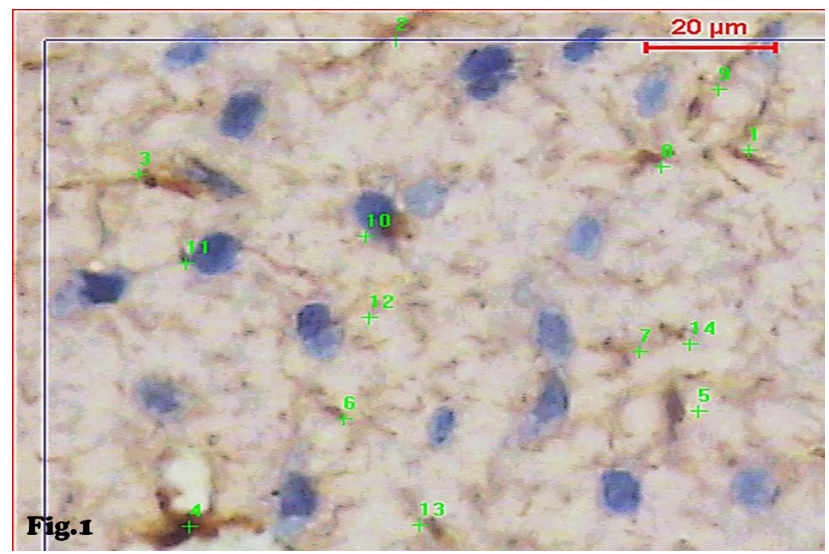

Fig. 1: A photomicrograph of a section in the external pyramidal layer of the cerebral cortex of frontal lobe of an adult male albino rat showing the counting of astrocytes. (Immunostaining for GFAP; X400)

Estimation of the mean cytoplasmic / nuclear ratio (CNR) of cortical pyramidal cells ${ }^{[27]}$.

(CNR) was calculated using the following formula:

$(\mathrm{CNR})=$ cytoplasmic volume / nuclear volume .

The cytoplasmic and nuclear volumes were measured as the following:

The mean of longest diameters of nuclei and cell bodies of pyramidal cells were measured in 10 different fields at direct magnification of 1000/slide and photographed using (JEOLJEM-100 SX electron microscope, Japan) at the electron microscopic unit, Faculty of Medicine, Tanta University.

The volume was measured using the following formula:

Volume $=\pi / 6 \times \mathrm{d}^{\wedge 3}$ ( $\mathrm{d}$ is the longest diameter $)$.

- The mean nuclear volume was measured in each group.

- The mean cytoplasmic volume was measured in each group as:

The mean cell body volume - the mean nuclear volume.

- So, (CNR) was measured as: (Cell body volume nuclear volume) / nuclear volume ${ }^{[28]}$ (Figure 2).

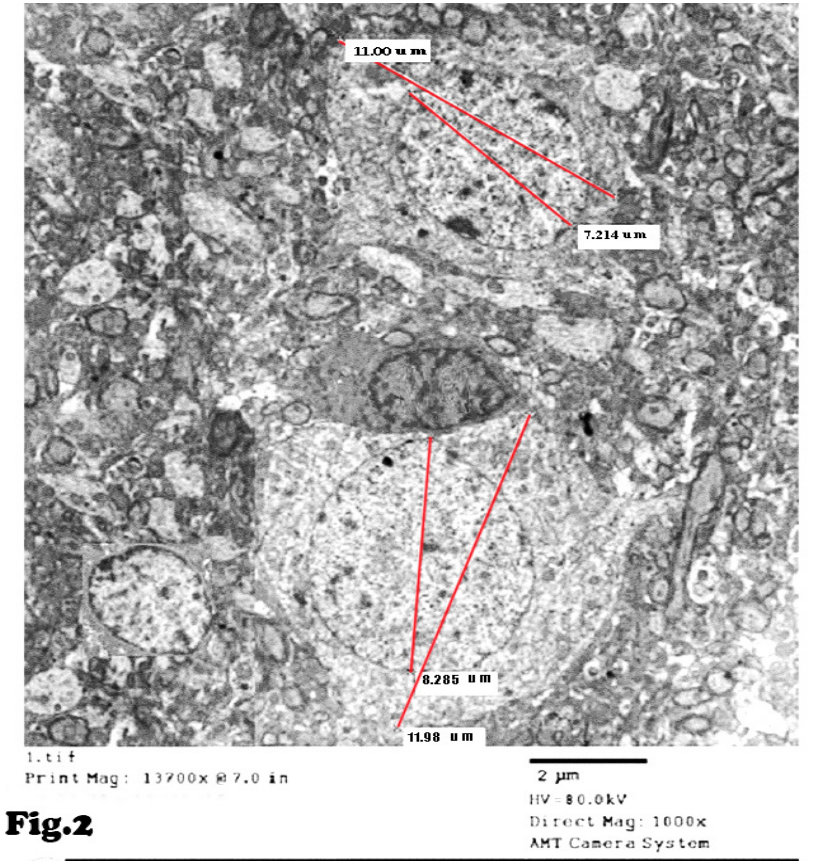

Fig. 2: An electron micrograph of an ultrathin section in the cerebral cortex of frontal lobe of an adult male albino rat showing the measurement of diameters of two pyramidal cell bodies and their nuclei. (TEM; $\times 1000$ direct and 13700 print)

\section{Statistical Analysis}

The following morphometric measurements were statistically analyzed:

1. The number of anti-GFAP immune-stained astrocytes $^{[23]}$

2. The nuclear, cytoplasmic, cell body volumes and cytoplasmic/nuclear ratio $(\mathrm{CNR})^{[29]}$

These measurements in all groups were expressed as mean \pm standard deviation (SD) and independent t-test was performed to compare each experimental group versus the control one. Data were analyzed using (SPSS) 16.0 software (SPSS Inc., Chicago, Illinois, USA). The difference was considered significant when probability of differences $P \leq 0.05$, highly significant if $P<0.001$ and non-significant if $P>0.05$.

\section{RESULTS}

\section{3-1. Light microscopic examination and immunohistochemical results}

\section{Hematoxylin \& Eosin $(H \& E)$ and Toluidine blue stains}

\section{Group I (control group)}

Negative and vehicle control subgroups showed the same results. Sections revealed organized and regularly arranged 
six layers of gray matter. These layers were arranged from outer to inner into, outer molecular (plexiform) layer, external granular layer, external pyramidal cell layer, internal granular layer, internal pyramidal and lastly the polymorphic cell layer. The pia mater covered the molecular layer (Figure 3A).

The outer molecular layer showed neuroglial cells. The external granular layer revealed granule cells characterized by their rounded cell bodies and large prominent nuclei. Also, small sized pyramidal cells were present in this layer. The external pyramidal layer showed medium sized pyramidal cells with triangular shaped cell bodies, basophilic cytoplasm, rounded nuclei and apical dendrites. Also, a blood vessel was seen (Figure 3B).

The internal granular layer showed rounded non pyramidal granule cells with open face nuclei. The internal pyramidal layer contained large sized pyramidal cells with triangular shaped cell bodies, basophilic cytoplasm, rounded nuclei and long apical dendrites. The ground substance between the nerve cells was normally occupied with homogenous eosinophilic neuropil with blood vessels and nuclei of glial cells in between (Figure 3C).

Examination of toluidine blue sections showed the pyramidal cells characterized by their triangular-shaped cell bodies with large rounded nuclei and long apical dendrites. (Figure 3D).

\section{Tramadol group (group II)}

Examination of sections revealed loss of organization of layers, dilated blood vessels with wide perivascular space (Figure 4A). The molecular layer revealed deformed neurons surrounded by haloes and other deformed neurons with acidophilic cytoplasm (red neurons). The external granular layer showed granule cells with deeply stained pyknotic nuclei. In the external pyramidal layer, pyramidal cells appeared with pyknotic deeply stained nuclei and surrounded by haloes. The neuropil was vacuolated. The internal granular layer showed granule cells with dark nuclei and others with karyolitic nuclei, deformed neurons, dilated and congested blood vessels and other neurons with acidophilic cytoplasm (red neuron) were seen. In the internal pyramidal layer, deformed neurons appeared with deeply stained nuclei and surrounded by haloes. Dilated congested blood vessels and red neurons could be seen (Figure 4B\&C).

Examination of toluidine blue stained sections revealed deformed neurons with irregularly shaped cell bodies surrounded by haloes. Dilated blood vessels could be noticed (Figure 4D).

\section{Tramadol withdrawal group (group III)}

Sections showed mildly affected cerebral cortex architecture with nearly normal arrangement of the cerebral cortex layers and the pia mater covering the molecular layer was seen (Figure 5A).

The molecular layer showed glial cells. The external granular layer showed normal granule cells with open face nuclei, while other neurons were still deformed. In the external pyramidal layer, some pyramidal cells appeared normal with long apical dendrites, but red neurons were still present. In the internal granular layer some granule cells appeared normal with open face nuclei, while others still had deeply stained nuclei and surrounded by haloes. In the internal pyramidal layer most pyramidal cells appear with their normal shape, rounded nuclei and long apical dendrites. However, other pyramidal cells were deformed with deeply stained nuclei and surrounded by haloes. Also, a blood vessel was seen still dilated, congested and surrounded by perivascular space (Figures 5B\&C)

Examination of toluidine blue stained sections showed most pyramidal cells with their normal shape, triangular cell bodies, rounded nuclei and long apical dendrites, while others were still deformed with pyknotic nuclei and surrounded by haloes (Figure 5D).

\section{GFAP immunohistochemistry}

Control group (group I): GFAP immunohistochemical stain revealed astrocytes with its star-shaped appearance and slim bodies with thin long processes (Figure 6A).

Tramadol group (group II): Active astrocytes were defined as GFAP-positive stained cells that showed hypertrophy of their cell bodies with increased number and thickness of their processes so increased GFAP immunoreactivity (Figure 6B).

Tramadol withdrawal group (group III): Astrocytes showed mild cell body hypertrophy and apparent thin processes (Figure 6C).

\section{3-2. Transmission electron microscopic examination}

\section{Control group (group I)}

Ultrathin sections showed the pyramidal cells which with their long apical dendrites, large rounded regular nuclei and prominent nucleoli (Figure 7A). The cytoplasm showed normal-shaped mitochondria with normal cristae pattern, normal-shaped rough endoplasmic reticulum, and multiple free ribosomes (Figure 7B). A myelinated axon showed regular smooth contour of its myelin sheath and another axon was un-myelinated. Normal-shaped mitochondria with normal cristae pattern appeared within their axoplasm (Figure 7C).

\section{Tramadol group (group II)}

The pyramidal cells showed irregular shaped nuclei with marked indentation of their membranes and partial chromatin condensation. The cytoplasm of a pyramidal cell showed dilated rough endoplasmic reticulum (rER) and swollen mitochondria with destructed cristae (Figures 8A\&B\&C). Myelinated axons appeared irregular in outlines with discontinuity in their myelin sheath and the mitochondria appeared markedly swollen with disrupted cristae within the axoplasm (Figure 8D).

\section{Tramadol withdrawal (group III)}

Some pyramidal cells nuclei appeared with their 
regular contour while others still irregular in shape and the rER was still dilated. Some myelinated axons showed splitting in their walls and others showed regular contour (Figures 9A\& B).

\section{Morphometric results}

\section{Mean number of anti-GFAP stained astrocytes}

The mean number of anti-GFAP stained astrocytes in control group was $26.9 \pm 6.75$. In tramadol group, the mean number of anti-GFAP stained astrocytes was $59.96 \pm 14.32$ with $P$ value 0.001 which was highly significantly increased as compared to the control group. However, in tramadol withdrawal group, significant changes were still present (37.67士9.93) P value 0.012 (Table 1 and Histogram 1).

\section{Mean cytoplasmic/ nuclear ratio of pyramidal cells}

The mean nuclear volume of pyramidal cells in control group was $263.9 \pm 62.6$. In tramadol group, the mean nuclear volume was decreased $(113.7 \pm 23.7)$ with $P$ value 0.001 (highly significant decrease compared to control group). In tramadol withdrawal group the mean nuclear volume of pyramidal cells still showed significant change (186.9 \pm 20.1$)$ p value 0.03 (Table 2 and Histogram 2).

The mean cell body volume of pyramidal cells in control group was $839.4 \pm 120$. The mean cell body volume of pyramidal cells was significantly decreased in tramadol group $(654.13 \pm 148.9)$ compared to control group ( $p$ value 0.002 ). In tramadol withdrawal group the mean cell body volume of pyramidal cells was $699 \pm 129.4$ with $p$ value 0.037 (significantly decreased than control group) (Table 3 and Histogram 3).

The mean cytoplasmic volume of pyramidal cells in control group was $575.5 \pm 87.6$. The mean cytoplasmic volume of pyramidal cells in tramadol group was $540.48 \pm 125.4$ with $p$ value 0.564 (non-significant changes compared to control group). In tramadol withdrawal group the mean cytoplasmic volume of pyramidal cells was $512.1 \pm 116.6$ with $p$ value 0.296 which was not significantly decreased than control group (Table 4 and Histogram 4).

The mean cytoplasmic/nuclear ratio of pyramidal cells in the control group was $2.25 \pm 0.471$. The mean cytoplasmic/ nuclear ratio of pyramidal cells in tramadol group was $6.124 \pm 1.287$ with $p$ value 0.001 which was highly significantly increased than control group. In tramadol withdrawal group, the mean cytoplasmic/nuclear ratio was $2.8 \pm 0.58$ with $P$ value 0.2 (no significant change compared to control group) (Table 5 and Histogram 5).

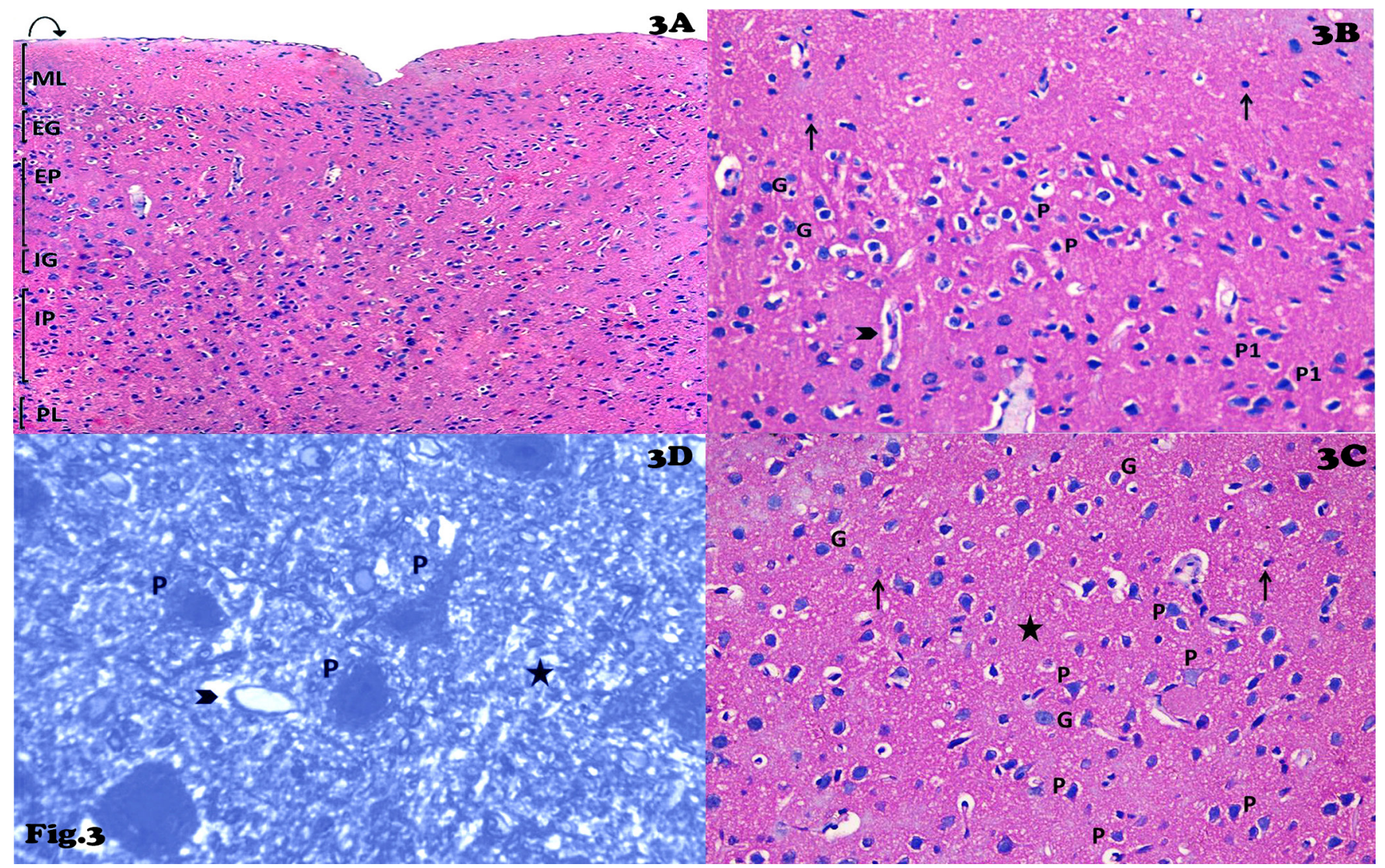

Fig. 3: Photomicrographs of sections in the cerebral cortex of frontal lobe of adult control albino rats showing:

(3A): Well organized regularly arranged six layers from outer to inner surface: Molecular layer (ML), external granular (EG), external pyramidal (EP), internal granular (IG), internal pyramidal (IP) and polymorphic layer (PL). The pia mater covers the molecular layer (curved arrow). (H.\&E., $\times 100)$

(3B): The molecular layer with neuroglial cells (thin arrow), the external granular layer with Granular cells (G) and the external pyramidal layer with small (P) and medium sized pyramidal cells (P1). Blood vessel is noticed (arrow head). (H.\& E., $\times 400)$.

(3C): The internal granular layer shows rounded non pyramidal granular cells $(\mathrm{G})$ with open face nuclei. The internal pyramidal layer reveals large sized pyramidal cells (P). Glial cells can be seen (thin arrows). the eosinophilic neuropil (star). (H.\&E., $\times 400)$

(3D): Normal pyramidal cells (P) with apical dendrites. A blood vessel (arrow head) is observed in the neuropil (star). (Toluidine blue stain; X 1000). 


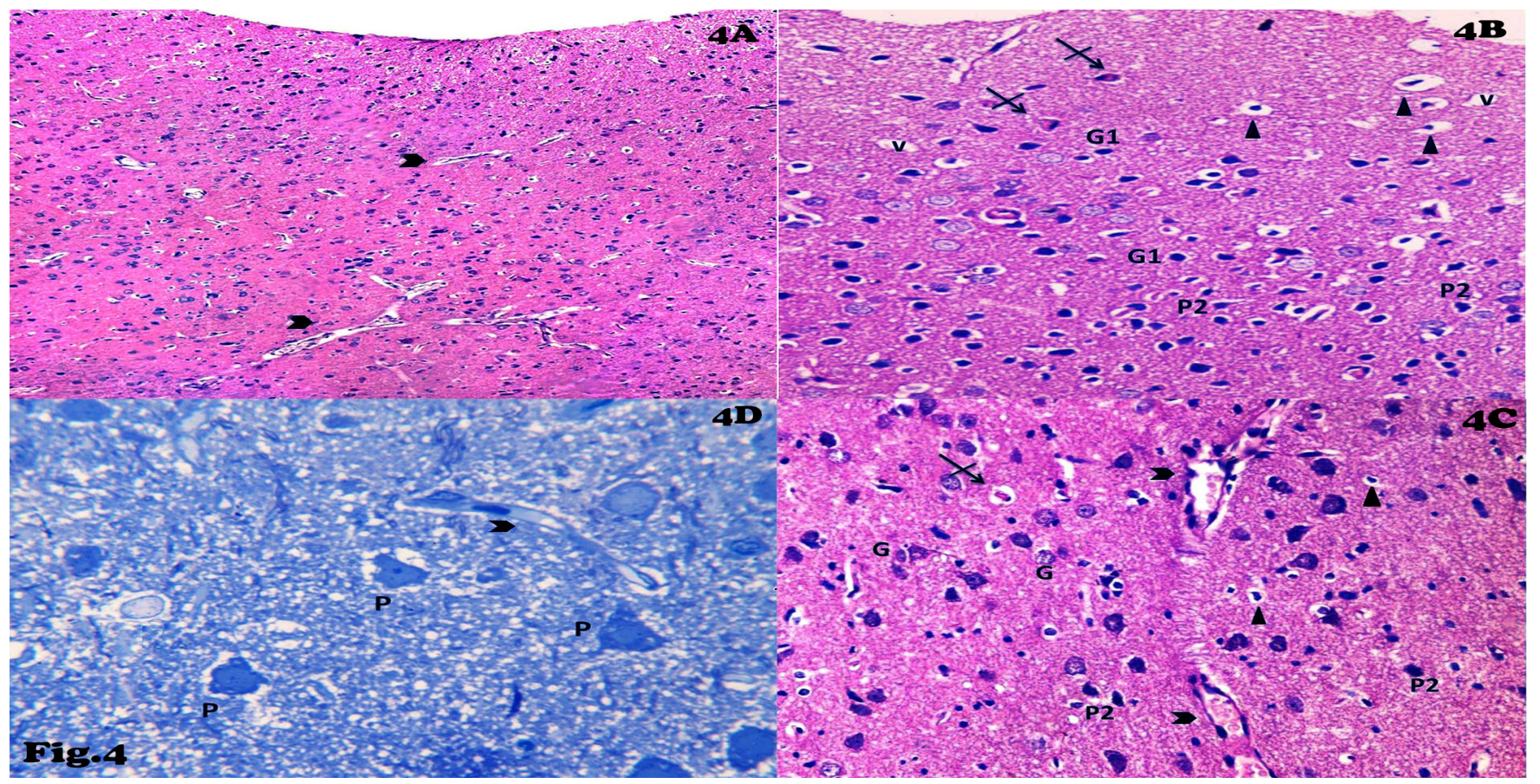

Fig. 4: Photomicrographs of sections in the frontal lobe of cerebral cortex of adult albino rats of group (II) showing:

(4A): Loss of the organization of layers and dilated blood vessels with wide perivascular spaces (arrow heads). (H.\&E., $\times 100$ ).

(4B): The molecular layer shows deformed neurons surrounded by haloes (triangles) and shows red neurons (crossed arrows). The external granular layer shows granule cells with deeply stained pyknotic nuclei (G1). In the external pyramidal layer, deformed neurons with deeply stained nuclei, surrounded by haloes (P2) are observed. Neuropil appears vacuolated(V). (H.\&E., $\times 400)$.

(4C): The internal granular layer shows granule cells with dark nuclei and others with karyolitic nuclei (G), deformed neurons (P2), dilated and congested blood vessels (arrow heads) and neurons with acidophilic cytoplasm (red neuron) (crossed arrow). (H.\&E., $\times 400)$.

(4D): Deformed neurons with irregularly shaped cell bodies and surrounded by haloes (P). A dilated blood vessel (arrow head) is noticed in the neuropil. (Toluidine blue stain; X 1000).

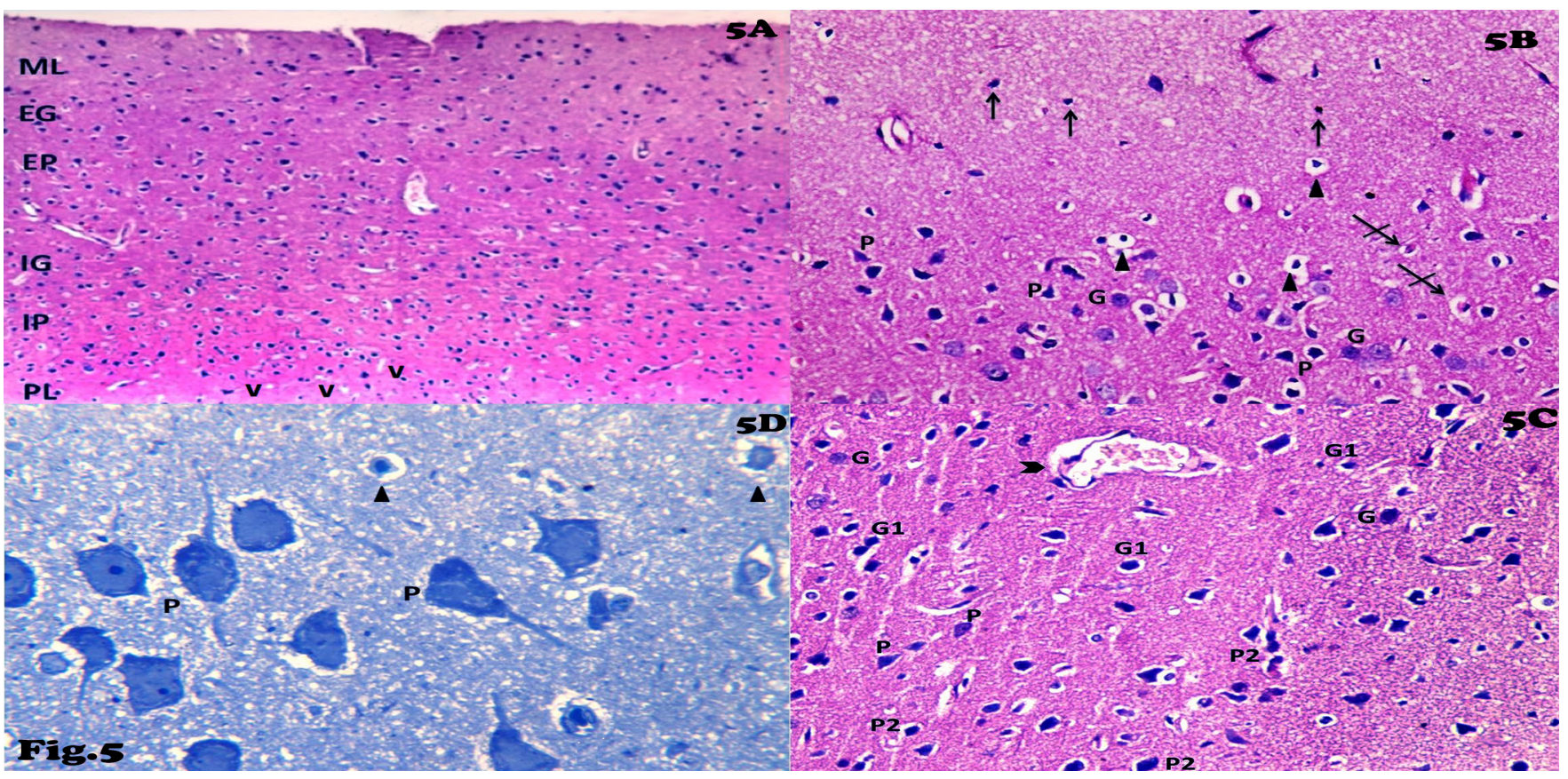

Fig. 5: Photomicrographs of sections in the cerebral cortex of frontal lobe of adult albino rats from group (III) showing:

(5A): Mildly affected cerebral cortex architecture with nearly normal arrangement of the cerebral cortex layers. (H.\&E., $\times 100)$.

(5B): The molecular layer shows glial cells (arrows). The external granular layer reveals normal granule cells (G) and other deformed neurons (triangles). The external pyramidal layer shows normal pyramidal cells $(\mathrm{P})$ and red neurons are still present (crossed arrows). (H.\&E., $\times 400)$.

$(5 \mathrm{C})$ : The internal granular layer shows nearly normal granule cells and open face nuclei $(\mathrm{G})$, other granule cells still have deeply stained nuclei and surrounded by haloes (G1). The internal pyramidal layer shows most pyramidal cells with their normal shape (P). Other deformed neurons are deeply stained and surrounded by haloes (P2). A dilated congested blood vessel and surrounded by perivascular space (arrow head) can be seen. (H.\&E., $\times 400$ ).

(5D): Most pyramidal cells with their normal shape $(\mathrm{P})$ while other deformed neurons still showing pyknotic nuclei and surrounded by haloes (triangles). (Toluidine blue stain; X 1000) 


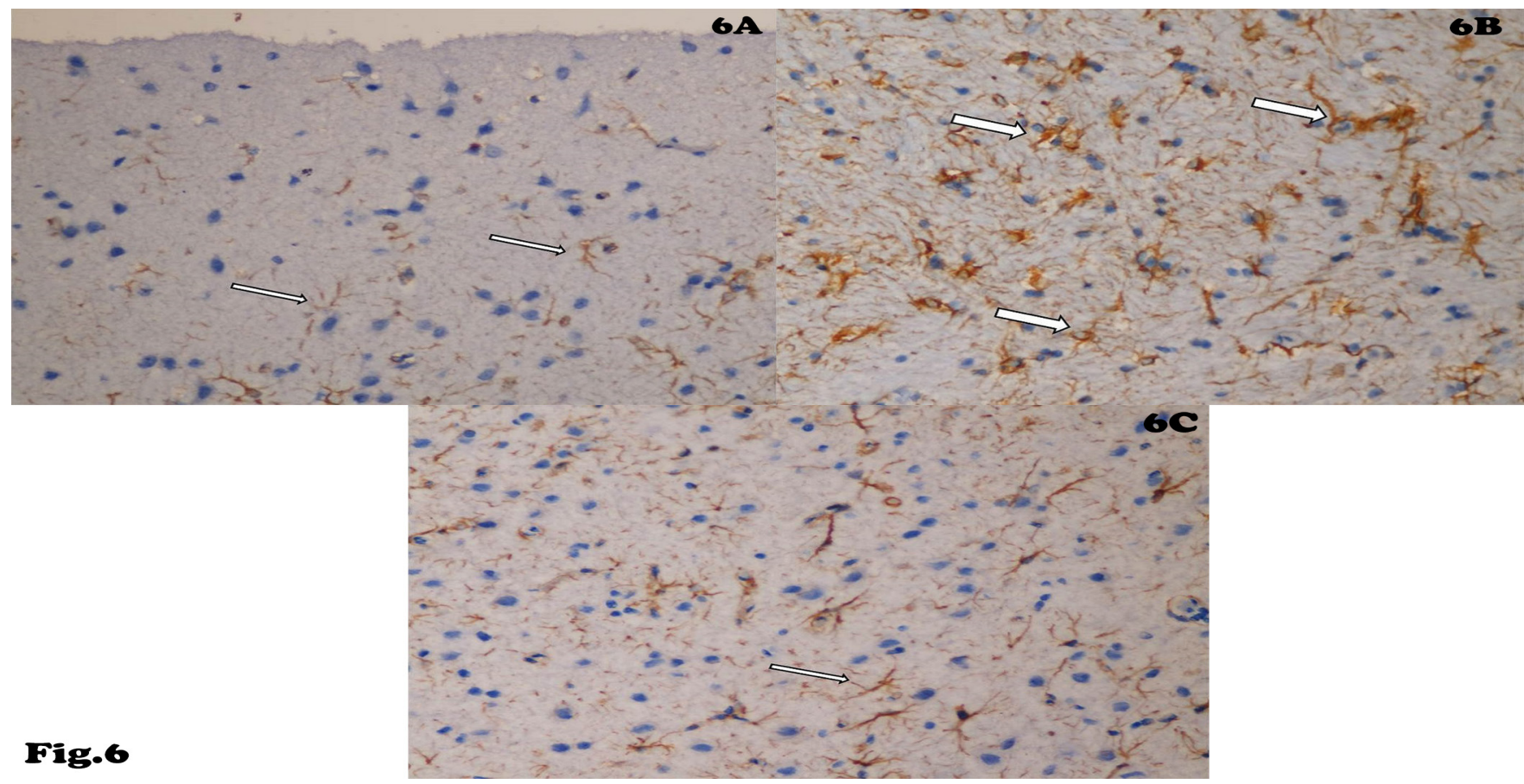

Fig. 6: Photomicrographs of sections in the external pyramidal layer of the cerebral cortex of adult albino rats with GFAP immunohistochemical stain showing: (6A): Astrocytes in the control group having star-shaped appearance with slim bodies and thin long processes (thin white arrows). (Immunostaining for GFAP; $\mathrm{X} 400)$

(6B): Astrocytes in tramadol group with cell body hypertrophy, with increased number and thickness of dendritic processes so increased GFAP immunoreactivity (thick white arrows). (Immunostaining for GFAP; X 400).

(6C): Astrocytes in tramadol withdrawal group with less cell body hypertrophy and apparent thin processes (thin white arrows). (Immunostaining for GFAP; $\mathrm{X} 400)$.
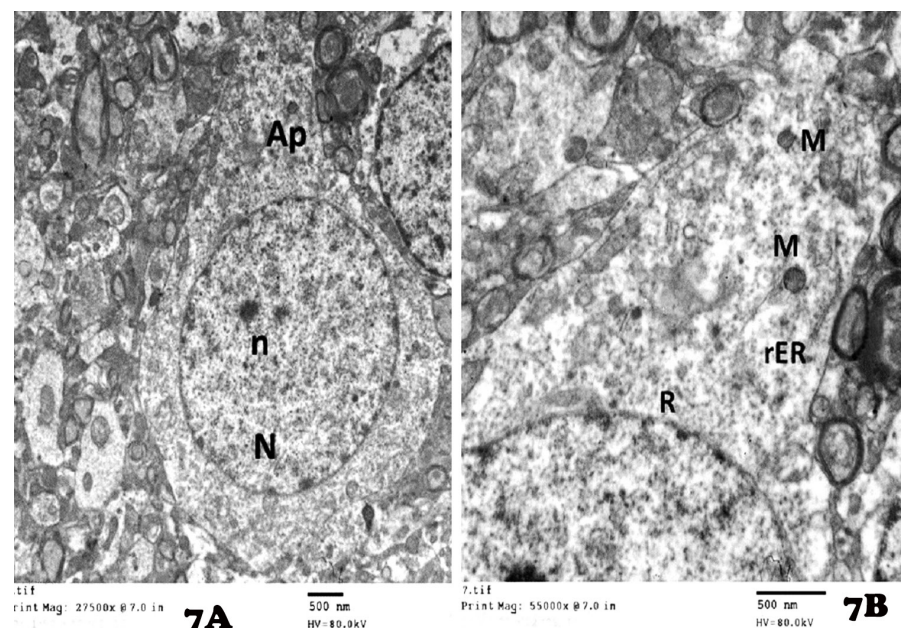

7A

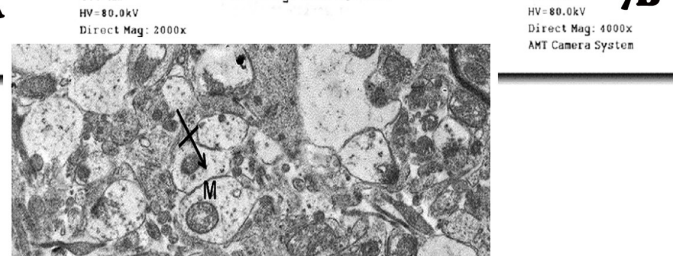

Fig. 7: Electron micrographs of ultrathin sections in the cerebral cortex of frontal lobe of the control albino rats showing:

(7A): A pyramidal cell with long apical dendrite (Ap), large rounded regular nucleus $(\mathrm{N})$ and prominent nucleolus (n). (TEM; $\times 2000$ direct magnification).

(7B): The pyramidal cell cytoplasm shows normal mitochondria with normal cristae pattern $(\mathrm{M})$, rough endoplasmic reticulum (rER) and multiple free ribosomes $(\mathrm{R})$. (TEM; $\times 4000)$.

(7C): A myelinated axon with regular smooth contour of its myelin sheath (arrow) and an un-myelinated (crossed arrow). Normal-shaped mitochondria with normal cristae pattern (M) appear within their axoplasm. $($ TEM; $\times 3000)$.

Fig.7

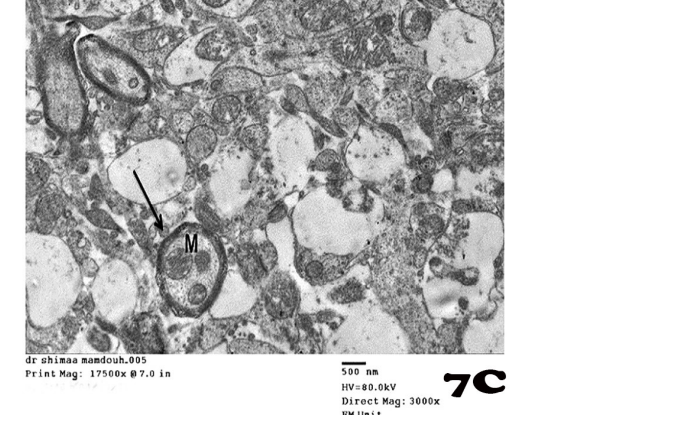



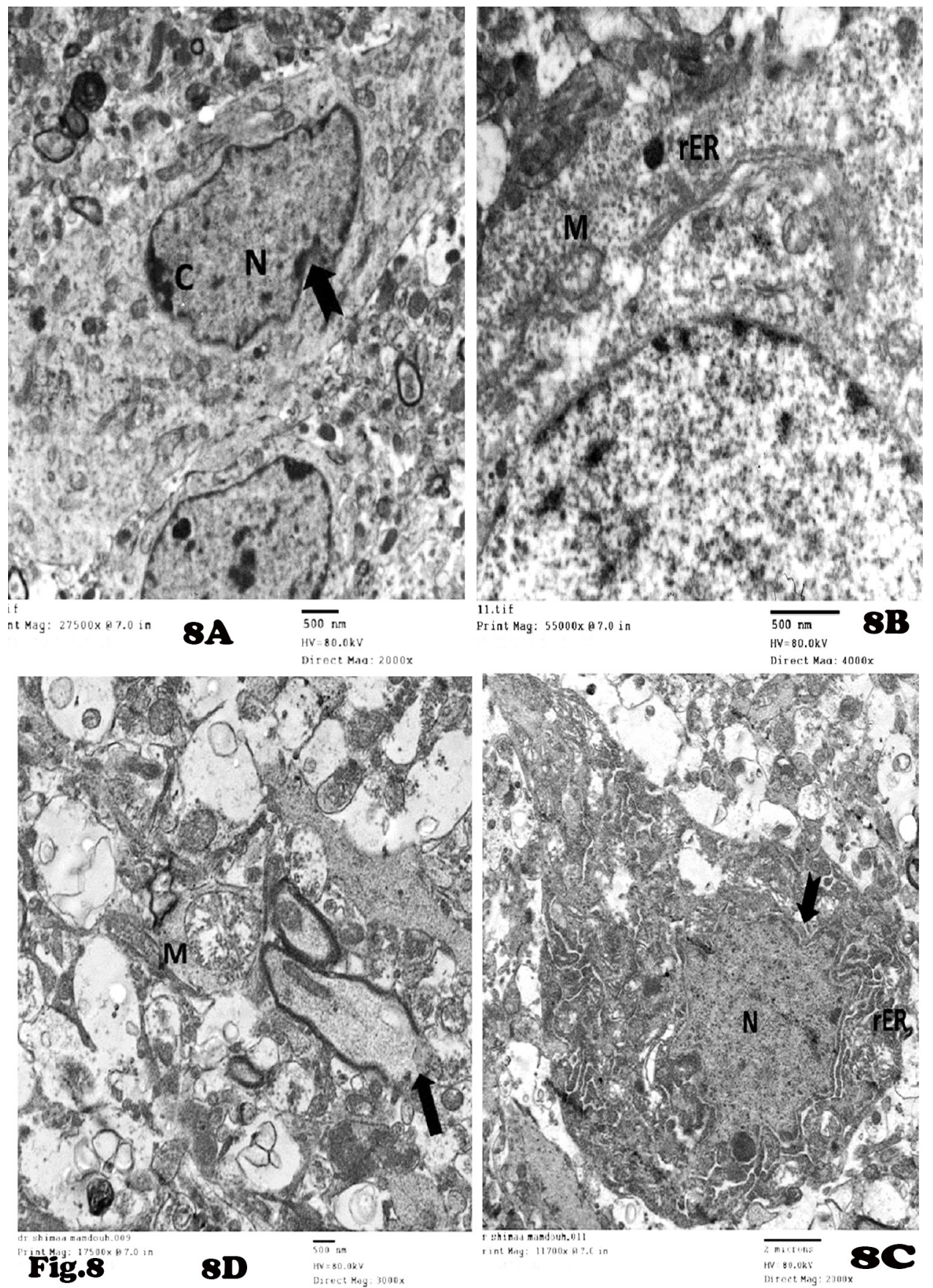

Fig. 8: Electron micrographs of ultrathin sections in the cerebral cortex of frontal lobe of group (II) showing:

(8A): Irregularly shaped nucleus $(\mathrm{N})$ with marked indentations (notched arrow) and partial chromatin condensation $(\mathrm{C})$. (TEM; $\times 2000)$.

(8B): Cytoplasm of a pyramidal cell with dilated rough endoplasmic reticulum $(\mathrm{rER})$ and swollen mitochondria with destructed cristae $(\mathrm{M})$. $(\mathrm{TEM}$; $\times 4000)$. $(8 \mathrm{C})$ : Irregularly shaped heterochromatic nucleus $(\mathrm{N})$ with marked indentations in its membrane (notched arrow) and dilated rough endoplasmic reticulum (rER). (TEM; × 2000).

(8D): Irregular outline of myelinated axons with discontinuity in its myelin sheath and splitting in their walls (thick arrow). Swollen mitochondria (M) with disrupted cristae within the axoplasm can be seen. (TEM; $\times 3000)$. 

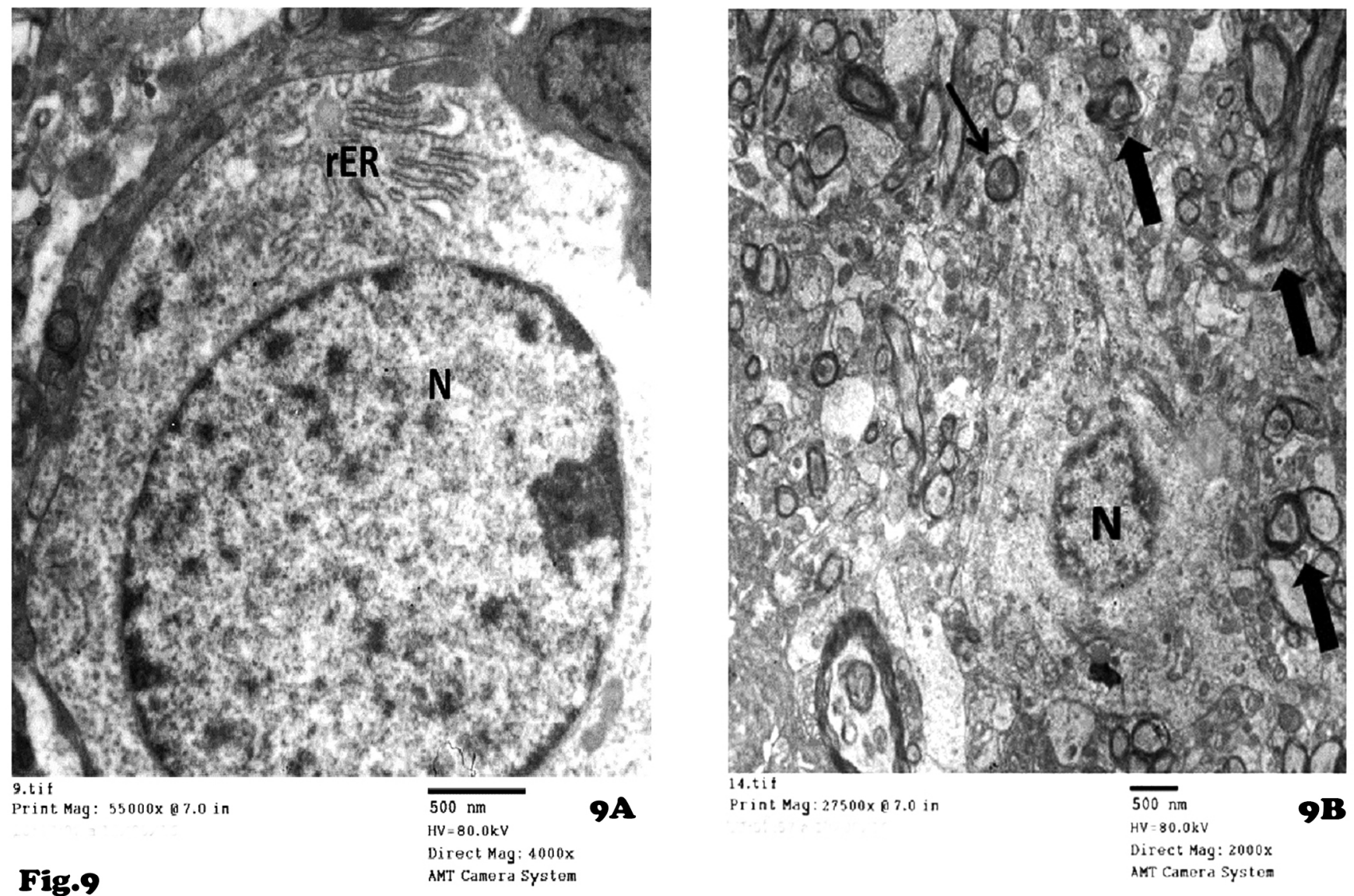

Fig. 9: Electron micrographs of ultrathin sections in the cerebral cortex of frontal lobe group (III) showing:

(9A): Pyramidal cell nucleus regaining its regular contour $(N)$. Some rough endoplasmic reticulum is still dilated (rER). (TEM; $\times 4000)$.

(9B): A pyramidal cell with irregular-shaped nucleus $(\mathrm{N})$. Some myelinated axons show splitting in their walls (thick arrows). Others show regular contour (thin arrow). (TEM; $\times 2000)$

Table 1: Mean number of anti-GFAP stained astrocytes in the three different groups

\begin{tabular}{lccc}
\hline New & Range & Mean \pm S. D & p. value \\
\hline Control & $2.27-105.57$ & $26.90 \pm 6.75$ & \\
Tramadol hydrochloride & $6.19-441.2$ & $59.96 \pm 14.32$ & $0.001^{* *}$ \\
$\begin{array}{l}\text { Tramadol hydrochloride } \\
\text { withdrawal }\end{array}$ & $6.69-108.32$ & $37.67 \pm 9.93$ & $0.012^{*}$ \\
\hline$P$ value $>0.05$ & Non-significant difference. & \\
$P$ value $\leq 0.05^{*}$ & Significant difference. & \\
$P$ value $\leq 0.001^{* *}$ & Highly significant difference & \\
& &
\end{tabular}

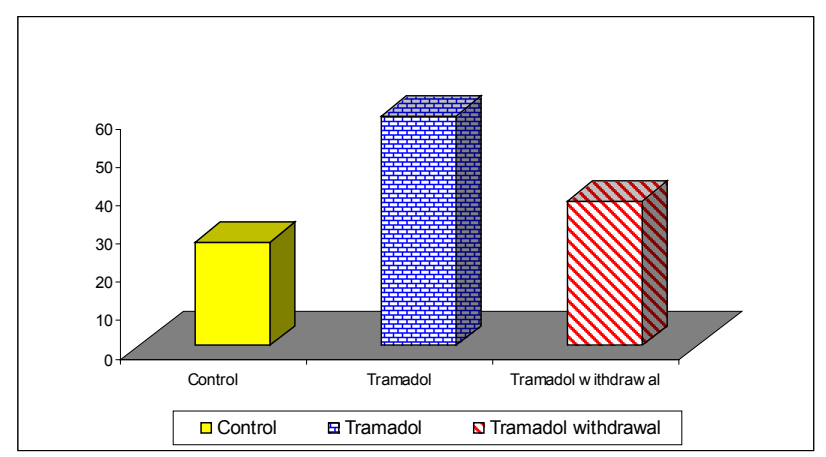

Histogram 1: Mean numbers of anti- GFAP stained astrocytes in the different groups
Table 2: Mean nuclear volume of pyramidal cells in microliter in the three different groups

\begin{tabular}{lccc}
\hline Nuclear volume & Range & Mean \pm S. D & p. value \\
\hline Control & $196.47-395.13$ & $263.9 \pm 62.6$ & \\
$\begin{array}{l}\text { Tramadol hydrochloride } \\
\text { Tramadol hydrochloride }\end{array}$ & $46.8-290.16$ & $113.7 \pm 23.7$ & $0.001^{* *}$ \\
withdrawal & $146.71-209.82$ & $186.9 \pm 20.1$ & $0.03^{*}$ \\
\hline$P$ value $>0.05$ & Non-significant difference. & \\
$P$ value $\leq 0.05^{*}$ & Significant difference. & \\
$P$ value $\leq 0.001^{* *}$ & Highly significant difference & \\
& &
\end{tabular}

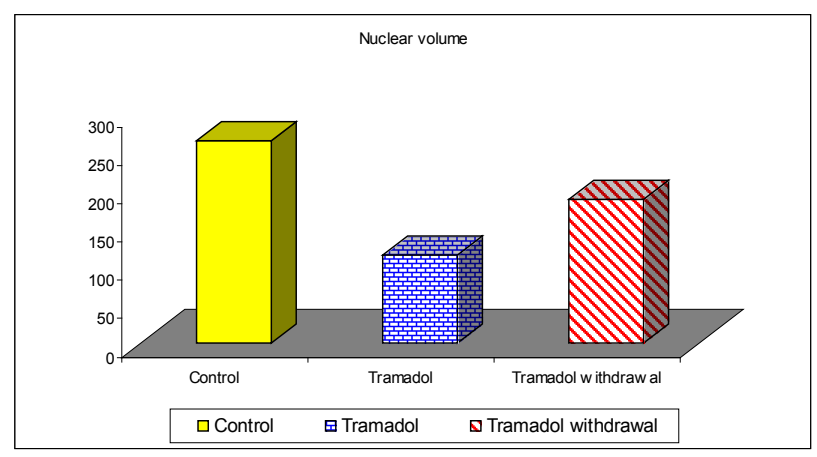

Histogram 2: Mean nuclear volume of pyramidal cells in microliter in the three different groups 
Table 3: Mean cell body volume in microliter in the three different groups

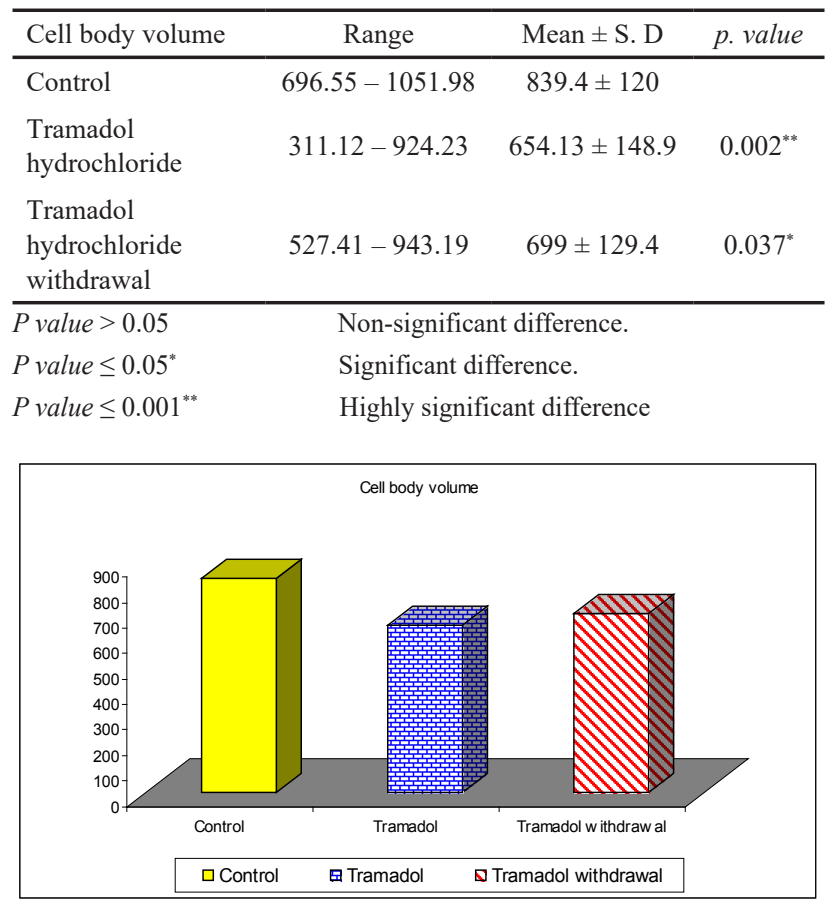

Histogram 3: Mean cell body volume of pyramidal cells in microliter in the three different groups

Table 4: Mean cytoplasmic volume in microliter in the three different groups

\begin{tabular}{lccc}
\hline Cytoplasmic Volume & Range & Mean $\pm \mathrm{S} . \mathrm{D}$ & p. value \\
\hline Control & $430.72-693.49$ & $575.5 \pm 87.6$ & \\
$\begin{array}{l}\text { Tramadol } \\
\text { hydrochloride }\end{array}$ & $262.07-720.89$ & $540.48 \pm 125.4$ & 0.564 \\
$\begin{array}{l}\text { Tramadol } \\
\text { hydrochloride } \\
\text { withdrawal }\end{array}$ & $323.94-737.77$ & $512.1 \pm 116.6$ & 0.296 \\
\hline $\begin{array}{l}P \text { value }>0.05 \\
P \text { value } \leq 0.05^{*}\end{array}$ & Non-significant difference. & \\
$P$ value $\leq 0.001^{* *}$ & Significant difference. & \\
& Highly significant difference &
\end{tabular}

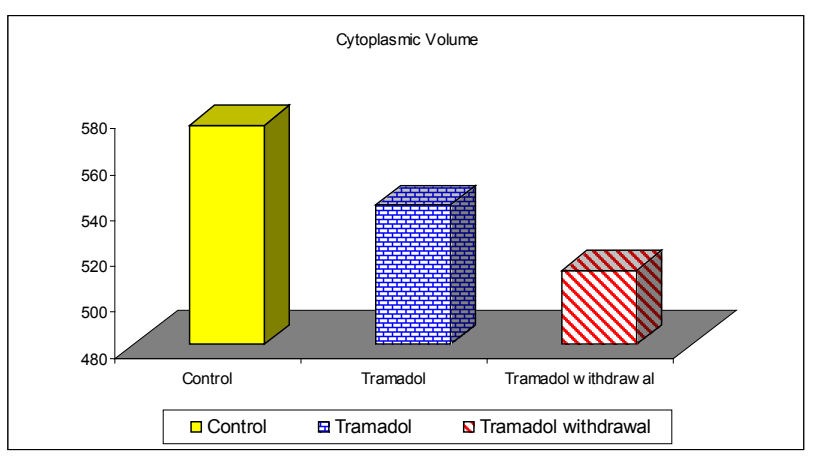

Histogram 4: Mean cytoplasmic volume of pyramidal cells in microliter in the three different groups
Table 5: Mean cytoplasm / nuclear ratio in the three different groups

\begin{tabular}{lccc}
\hline Cytoplasm / Nuclear ratio & Range & Mean \pm S. D & p. value \\
\hline Control & $1.48-3.45$ & $2.25 \pm 0.471$ & \\
Tramadol hydrochloride & $1.81-8.81$ & $6.124 \pm 1.287$ & $0.001^{* *}$ \\
$\begin{array}{l}\text { Tramadol hydrochloride } \\
\text { withdrawal }\end{array}$ & $1.59-4.79$ & $2.8 \pm 0.58$ & 0.2 \\
\hline$P$ value $>0.05$ & Non-significant difference. & \\
$P$ value $\leq 0.05^{*}$ & Significant difference. & \\
$P$ value $\leq 0.001^{* *}$ & Highly significant difference & \\
& & &
\end{tabular}

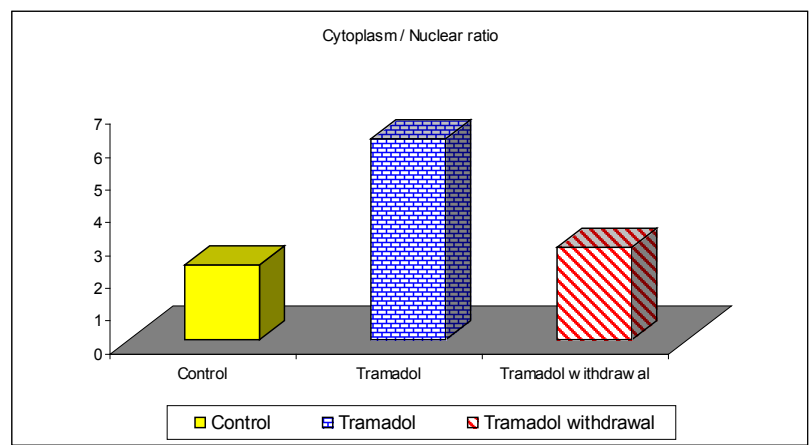

Histogram 5: Mean cytoplasmic/nuclear ratio of pyramidal cells in the three groups

\section{DISCUSSION}

The current study aimed to examine the histological and morphometric changes in the cerebral cortex of the frontal lobe of adult male albino rats under the effect of tramadol hydrochloride as well as the effect of its withdrawal.

In the present work, after administration of tramadol hydrochloride for four weeks sections revealed marked disorganization of cortical layers, pyramidal and granule cells lost their normal shape and surrounded by haloes, the pyramidal cells showed indentations in their nuclear membranes, partial condensation of chromatin, swollen mitochondria and dilated rER, also splitting of the myelin sheath of the myelinated axons was observed. These results coincide with Omar ${ }^{[30]}$ who reported similar results like shrunken pyramidal cells, dilated rER and ill-defined myelinated axons.

These results also are in agreement with Liu et al. ${ }^{[31]}$ who reported that long-term use of opioids resulted in neuronal damage and reported apoptotic cells with cytoplasmic contraction and nuclear condensation in rat's brain after opioids administration. Moreover, prolonged opiate therapy could decrease the renewal and survival of new neurons in the mature adult brain by decreasing DNA synthesis ${ }^{[32]}$.

In this study after four weeks of tramadol administration, marked vacuolations within the neuropil was observed. These results coincide with Brown et al. and Zarnescu et al. ${ }^{[33,34]}$ who reported vacuolization and some shrunken pyramidal 
cells and accused it due to exposure to free radicals that were released from tissue damage and destroyed cell organelles. Excess exposure to free radicals led to oxidative stress which is a disturbance in the balance between the production of reactive oxygen species (free radicals) and antioxidant defenses. Chronic opioid administration may be involved in oxidative stress with a significant decrease in the antioxidants in brain tissue ${ }^{[35,36]}$.

The brain is highly susceptible to damage by oxidative stress because of its high oxygen consumption and its low content of antioxidants. Oxidative stress can cause protein modifications which lead to decrease in enzymatic activity and loss of function ${ }^{[37,38]}$.

Mărgăritescu et al. ${ }^{[39]}$ stated that in the later stages of apoptosis, the cytoplasm became structureless and the nucleus showed more degeneration and appeared homogeneous and finally, the neurons were fragmented and phagocytized by macrophages.

Our results revealed red neurons in the molecular and internal pyramidal layers of the cerebral cortex. These results agree with the results observed by Mohamed et al. ${ }^{[40]}$ who studied the effect of combination of tramadol and clonazepam on brain and observed the appearance of degenerated red neurons and stated that red dead neuron or eosinophilic neuron degeneration is characterized by cell body shrinkage, loss of nissl bodies, intensely stained eosinophilic cytoplasm and a small darkly stained (pyknotic) nucleus that may undergo fragmentation (karyorrhexis). The red color is due to pyknosis of the nucleus and loss of nissl bodies which are normally stained blue on hematoxylin and eosin staining ${ }^{[41]}$.

Swollen mitochondria with loss of their cristae in the axons of neurons were demonstrated also in the tramadol-treated group. These changes in the mitochondria were a mechanism by which neurons respond to the free radicals which result from tissue damage ${ }^{[42]}$.

Increased perivascular space and dilatation of blood vessels found in this study. These results were also observed by Abou El Fatoh et al. ${ }^{[43]}$ who found congestion of blood vessels and neural degeneration following tramadol administration.

In this study, there was highly significant increase in the mean number and size of astrocytes in tramadol group with hypertrophy of their cell bodies and increased number and thickness of their processes. This result coincides with Mărgăritescu et al. ${ }^{[39]}$ who reported that after brain lesions, the degenerated neurons and fragmented cell bodies were remarkably surrounded by swollen astrocytes.

Kim and Dustin ${ }^{[44]}$ mentioned that astrocytes were the early responders to brain Injury. They explained their essential role in stimulating other cellular responses as they are the most numerous glial cells in CNS and became activated in case of tissue injuries as brain inflammation, infection or ischemia. Moreover, other researchers reported that after any degenerative brain injury, astrocytes react rapidly by producing more GFAP, leading to astrogliosis and proper glial scar formation ${ }^{[45]}$.

In our study there were significant decrease in the mean cell body volume, highly significant decrease in the mean nuclear volume and highly significant increase in their cytoplasmic / nuclear ratios of pyramidal cells in tramadol hydrochloride-treated group. These results are in agreement with Omar ${ }^{[30]}$ who found significant increase in the mean number of shrunken pyramidal cells in rats received repeated intraperitoneal injections of increasing doses of tramadol, also Nafea et al. ${ }^{[46]}$ reported that there was nuclear pyknosis in rats' brain cells treated by tramadol.

The cytoplasmic-nuclear correlation indicated the relative size of the nucleus to the cytoplasm. The increase in this ratio meant increased susceptibility of malignancy ${ }^{[47]}$. It is one of the characters of cell atypia used in assessment of premalignant lesions.

In our study after 4 weeks of tramadol withdrawal, brain tissues began to return towards normal morphology, as sections showed mildly affected cerebral cortex architecture with the pyramidal cells in the external and internal pyramidal layers appeared normal with long apical dendrites, except some pyramidal and granular cells were still deformed and some red neurons were still present. These results are in agreement with Khodeary et al. ${ }^{[48]}$ who stated that rat's brain examined after the withdrawal recovery period did not return back to normal control but showed marked reduction in cellular damage when compared to tramadol-treated groups. They reported regression of apoptotic changes previously induced by tramadol and return of apoptotic index towards normal value but still significantly different from control.

After four weeks of tramadol withdrawal, partial recovery of the morphometric findings occurred. The mean nuclear and cell body volumes were significantly smaller than control. However, the mean cytoplasmic/nuclear ratio showed non-significant changes compared to the control group. Although these results did not return to normal, they were better than tramadol-treated group. This also is coincided with Omar ${ }^{[30]}$ who found that the mean number of shrunken pyramidal cells was significantly decreased after withdrawal compared to tramadol-treated group. However, it was still higher than in the control group.

In addition, Nafea et $a l^{[46]}$ reported that the complete reversibility of the neurotoxic effects of tramadol wasn't achieved after withdrawal. They found apoptotic neurons with pyknotic nuclei and vacuolations of cytoplasm in H\&E stained sections of rats' brain after tramadol withdrawal.

The partial recovery of brain tissue after tramadol withdrawal was also supported by Iversen ${ }^{[49]}$ who stated that gradual improvement of opioid-induced toxic encephalopathy was observed after 4 weeks of exposure and nearly complete recovery was noticed after 6 months of exposure, as the nervous system differs from other body organs by its low regeneration capacity. The neurotoxicity is generally at least partially reversible, but complete recovery may take many months ${ }^{[48]}$. 
Finally, it could be concluded that tramadol hydrochloride administration affected the cerebral cortex and resulted in several histopathological and morphometric harmful effects which regressed to a lesser extent after its withdrawal.

\section{CONFLICTS OF INTEREST}

There are no conflicts of interest

\section{REFERENCES}

1. Inturrisi CE. Clinical pharmacology of opioids for pain. Clin J Pain. 2002; 18 (4): 3-13.

2. Herrera C, Bolton F, Arias AS, Harrison RA, Gutiérrez JM. Analgesic effect of morphine and tramadol in standard toxicity assays in mice injected with venom of the snake Bothrops asper. Toxicon. 2018; 154:35-41.

3. Kalso E, Edwards JE, Moore RA and McQuay HJ. Opioids in chronic non-cancer pain: Systematic review of efficacy and safety. Pain. 2004; 112 (3): 372-80.

4. Camilleri M, Lembo A, Katzka DA. Opioids in Gastroenterology: Treating Adverse Effects and Creating Therapeutic Benefits. Clin Gastroenterol H. 2017; 15(9):1338-49.

5. Pearson SA, Ringland C, Kelman C, Mant A, Lowinger J, Stark $\mathrm{H}$, et al. Patterns of analgesic and anti-inflammatory medicine use by Australian veterans. Intern Med J.2007; 37 (12): 798-805.

6. Shadnia S, Soltaninejad K, Heydari K, Sasanian G and Abdollahi M. Tramadol intoxication: A review of 114 cases. Hum Exp Toxicol. 2008; 27 (3): 201-5.

7. Fiaes GCdS, Roncon CM, Sestile CC, Maraschin JC, Souza RLS, Porcu M, et al. Panicolytic-like effect of tramadol is mediated by opioid receptors in the dorsal periaqueductal grey. Behav. Brain Res. $2017 ; 326: 52-8$

8. Gillen C, Haurand M, Kobelt DJ and Wnendt S. Affinity, potency and efficacy of tramadol and its metabolites at the cloned human mu-opioid receptor. N-S Arch Pharmacol. 2000; 362 (2): 116- 121.

9. Scott LJ and Perry CM. Tramadol: A review of its use in perioperative pain. Drugs. 2000; 60 (1): 139-176.

10. Grond S and Sablotzki A. Clinical pharmacology of tramadol. Clin Pharmacokinet. 2004; 43 (13): 879-923.

11. Keating GM. Tramadol sustained-release capsules. Drugs. 2006; 66 (2): 223-230.

12. Barkin RL. Extended-release tramadol (ULTRAM®ER): A pharmacotherapeutic, pharmacokinetic, and pharmacodynamic focus on effectiveness and safety in patients with chronic/ persistent pain. Am J Ther. 2008; 15 (2): 157-166.

13. Reinecke H and Sorgatz H. S3 guideline Lonts. Long- term administration of opioids for non-tumor pain. Schmerz. 2009; 23 (5): 440-447.

14. Chung JW, Zeng Y and Wong TK. Drug therapy for the treatment of chronic non-specific low back pain: Systematic review and meta-analysis. PAIN PHYSICIAN. 2013; 16 (6): 685-704.

15. Ghoneim FM, Khalaf HA, Elsamanoudy AZ, Helaly AN. Effect of chronic usage of tramadol on motor cerebral cortex and testicular tissues of adult male albino rats and the effect of its withdrawal: histological, immunohistochemical and biochemical study. Int J Clin Exp Pathol 2014; 7(11):7323-7341.

16. Lagard C, Chevillard L, Malissin I, Risède P, Callebert J, Labat L, et al. Mechanisms of tramadolrelated neurotoxicity in the rat: Does diazepam/ tramadol combination play a worsening role in overdose? Toxicol Appl Pharm. 2016; 310:108-19.

17. Faria J, Barbosa J, Leal S, Afonso LP, Lobo J, Moreira R, et al. Effective analgesic doses of tramadol or tapentadol induce brain, lung and heart toxicity in Wistar rats. Toxicology. 2017; 385:38-47.

18. Senay EC, Adams EH, Geller A, Inciardi JA, Munoz A, Schnoll SH, et al. Physical dependence on Ultram ${ }^{\circledR}$ (tramadol hydrochloride): both opioid-like and atypical withdrawal symptoms occur. DRUG ALCOHOL DEPEN. 2003; 69(3):233-41.

19. Epstein DH, Preston KL and Jasinski DR. Abuse liability, behavioral pharmacology, and physicaldependence potential of opioids in humans and laboratory animals: lessons from tramadol". Biol Psychol. 2006; 73 (1): 90-9.

20. Mannocchi G, Napoleoni F, Napoletano S, Pantano F, Santoni M, Tittarelli R, et al. Fatal selfadministration of tramadol and propofol: a case report. J Forensic LEG Med 2013; 20(6):715-9.

21. Matthiesen T, Wöhrmann T, Coogan TP and Uragg, H. The experimental toxicology of tramadol: An overview. Toxicol Lett. 1998; 95 (1): 63-71.

22. Bancroft JD and Gamble M. Theory and practice of histological technique. 6th ed. Churchil Livingstone. London, England: 2008; 121-132.

23. Afsari ZH, Renno WM and Abd-El-Basset E. Alteration of glial fibrillary acidic proteins immunoreactivity in astrocytes of the spinal cord diabetic rats. Anat Rec. 2008; 291 (4): 390-399.

24. Bozzola JJ and Russell LD. Electron microscopy in: Principles and techniques for biologists. 2nd ed. Jones and Bartlett, Sudbury, Massachusetts: 1999; 116-147. 
25. Kuo J. Electron microscopy: Methods and protocols. ACTA BIOCHIM POL. 2007; 56 (1): 195-197.

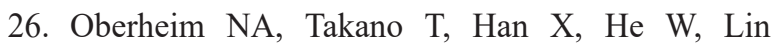
$\mathrm{JH}$, Wang $\mathrm{F}$, et al. Uniquely hominid features of adult human astrocytes. J Neurosci. 2009; 29 (10): 3276-3287.

27. Tipoe GL, White FH and Pritchett CJ. A morphometric study of histological variations during cellular differentiation of normal human colorectal epithelium. J. Anat. 1992; 181(2): 189-197.

28. Shubina OS and Egorova MV. Morphology and morphometry of neurons of the cerebral cortex of the brain cerebellum white rats under the influence of lead acetate. Res J Pharm Biol Chem Sci. 2016; 7 (5): 1404-1414.

29. Maskey D, Kim HG, Suh M, Roh GS, and Kim MJ. Alteration of glycine receptor immunoreactivity in the auditory brainstem of mice following three months of exposure to radiofrequency radiation at SAR 4.0 W/k. Int J Mol Med. 2014; 34 (2): 409-419.

30. Omar NM. Nigella sativa oil alleviates ultrastructural alterations induced by tramadol in rat motor cerebral cortex. JMicrosc Ultrastruct. 2016; 4(2): 76-84.

31. Liu LW, Lu J, Wang XH, Fu SK, Li Q and Lin FQ. Neuronal apoptosis in morphine addiction and its molecular mechanism. Int J Clin Exp Med. 2013; 6 (7): $540-545$.

32. Eisch AJ, Barrot M, Schad C.A, Self DW and Nestler EJ. Opiates inhibit neurogenesis in the adult rat hippocampus. Neurobiology in Proc Nati Acad Sci U S A. 2000; 97 (13): 7579-7584.

33. Brown DM, Donaldson K, Borm PJ, Schins RP, Dehnhardt M, Gilmour P, et al. Calcium and ROSmediated activation of transcription factors and TNFalpha cytokine gene expression in macrophages exposed to ultrafine particles. Am J Physiol-Lung C. 2004; 286 (2): 344-353.

34. Zarnescu O, Brehar FM, Chivu M and Ciurea AV. Immunohistochemical localization of caspase-3, caspase-9 and Bax in U87 glioblastoma xenografts. J Mol Histol. 2008; 39 (6): 561-569.

35. Abdel-Zaher AO, Abdel-Rahman MS and Elwasei FM. Protective effect of nigella sativa oil against tramadol-induced tolerance and dependence in mice. Role of nitric oxide and oxidative stress. Neurotoxicology. 2011; 32 (6): 725-733.

36. Mohamed HM and Mahmoud AM. Chronic exposure to the opioid tramadol induces oxidative damage, inflammation and apoptosis, and alters cerebral monoamine neurotransmitters in rats. BIOMED PHARMACOTHER. 2019; 110:239-47.
37. Butterfield DA, Castegna A, Lauderback CM and Drake J. Evidence that amyloid beta-peptideinduced lipid peroxidation and its sequelae in Alzheimer's disease brain contribute to neuronal death. Neurobiol Aging. 2002; 23(5): 655-664.

38. Butterfield DA, Reed T, Newman SF and Sultana R. Roles of amyloid beta-peptide-associated oxidative stress and brain protein modifications in the pathogenesis of Alzheimer's disease and mild cognitive impairment. Free Radical Bio Med. 2007; 43(5): 658-677.

39. Mărgăritescu O, Mogoantă L, Pirici I, Pirici D, Cernea D and Mărgăritescu CL. Histopathological changes in acute ischemic stroke. Rom J Morphol Embryo. 2009; 50 (3):327-339.

40. Mohamed TM, Abdel Ghaffar HM and El Husseiny RM. Effects of tramadol, clonazepam, and their combination on brain mitochondrial complexes. Toxicol Ind Health. 2015; 31 (12):1325-33.

41. Garman RH. Histology of the central nervous system. Toxicol Pathol.2011; 39(1): 22-35.

42. Wakabayashi T. Megamitochondria formation-physiology and pathology. J Cell Mol Med. 2002; 6 (4): 497-538.

43. Abou El Fatoh MF, Farag M, Sayed AE, Kamel MA, Abdel-HamidN, Hussein M etal. Some Biochemical, neurochemical, pharmacotoxicological and histopathological alterations induced by long-term administration of tramadol in male rats. Int J Pharma Sci. 2014; 4 (3): 565-571.

44. Kim JV and Dustin ML. Innate response to focal necrotic injury inside the blood-brain barrier. J Immunol. 2006; 177 (8): 5269-5277.

45. Sriram K, Benkovic SA, Hebert MA, Miller DB and O'Callaghan JP. Induction of gp130-related cytokines and activation of JAK2/STAT3 pathway in astrocytes precedes up-regulation of glial fibrillary acidic protein in the 1-methyl-4-phenyl-1,2,3, 6-tetrahydropyridine model of neurodegeneration: key signaling pathway for astrogliosis in vivo? J Biol Chem. 2004; 279 (19): 19936-19947.

46. Nafea OE, ElKhishin IA, Awad OA and Mohamed DA. A study of the neurotoxic effects of tramadol and cannabis in adolescent male albino rats. Int. J. Sci. Rep. 2016; 2 (7): 143-154.

47. Mehrotra R, Gupta A, Singh M and Ibrahim R. Application of cytology and molecular biology in diagnosing premalignant or malignant oral lesions. Mol Cancer. 2006; 5 (1): 11.

48. Khodeary MF, Sharaf El-Din AI and El Kholy SMS. (2010): A histopathological and 
immunohistochemical study of adult rats 'brain after long term exposure to Amadol (tramadol hydrochloride). Mansoura J Forensic Med Clin
Toxicol. 2010; 18 (1): 1-24.

49. Iversen L. Cannabis and the brain. Brain. 2003; 126 (6):1252-70. 
الملخص العربى

\section{التغييرات في القشرة المخية في الجرذان البيضاء البالغة تحت تأثير الترامادول \\ وتأثير إنسحابه: دراسة نسيجية و شكلية قياسية \\ شيماء ممدوح مطاوع، رباب محمد عامر، دعاء عادل هيبة، مجدى سعيد مصطقى \\ قسم التشريح وعلم الأجنة، كلية الطب، جامعة طنطا}

المقدمة: تعتبر المسكنات هي الأدوية الأكثر استخدامًا في جميع أنحاء العالم مثل هيدروكلوريد الترامادول (الأفيون) و الذى يعد عامل مسكن مخلَق يعمل بالوسائل المركزية على المخ ويستخدم لعلاج الألم المعتدل إلى الثديد مع آثار جانبية أقل من الأدوية الأفيونية التقليدية. الهدف من البحث: هدفت الدراسة الحالية إلى تقييم التأثثر المحتمل لعقار التر امادول هيدروكلوريد على القترة المخية للجرذان البيضاء البالغة والآثار المحتملة للإنسحاب باستخدام وسائل نسيجية و شكلية قياسية. مواد و طرق البحث: تم استخدام أربعة و عشرون من الفئران البيضاء البالغة بغض النظر عن الجنس وتم تقسيمها إلى ثلاث مجمو عات، مجمو عة ضابطة تتألف من ^ فئر ان وتم تقسيمها بشكل إضافي إلى مجمو عتين فر عيتين متساويتين: مجمو عة فر عية فئر ان تبقى دون أي دواء لمدة ؛ أسابيع و أخرى حيث اعطيت الفئر ان محلول الملح يو ميًا بالحقن داخل غثاء البريتون لمدة ؛ أسابيع و مجموعة الترمادول واشتملت على ^ فئر ان تلقت الجرعة العلاجية من الترامادول داخل غشاء البريتون لمدة ؛ أسابيع كما اشتملت مجمو عة الانسحاب على ^ فئر ان تلقت نفس جر عة مجمو عة تر امادول ثم أبقيت لمدة ء أسابيع أخرى دون علاج لدر اسة تأثثير الإنسحاب ثم تم فحص العينات التي تم الحصول عليها بو اسطة المجهر الضوئي والإلكترون. نتائج البحث: أظهرت المجموعة الضابطة الصورة النسيجية الطبيعية للقشرة الدماغية وكثفت مجمو عة التر امادول عن خلا فى تنظيم طبقات القترة المخية كما ظهرت بعضا من الخلايا الهرمية و الحبيبية متغلظة الأنوية ومحاطة بفر اغات كما أظهرت الخلايا النجمية تضخما فى الحجم مع زيادة فى سماكة زو ائدها وبالفحص بالمجهر الدقيق أظهرت الخلايا الهرمية أنوية غير متجانسة الكروماتين مع تعرج ملحوظ في جدار انها الى جانب المحاور العصبيية المايلينية التى أظهرت نشققاً في طبقات المايلين مع وجوود ميتوكوندريا متورمة في سيتوبلازم هذه المحاوركما أظهرت مجمو عة الإنسحاب أدلة على التحسن بالمقارنة مع مجمو عة التر امادول. الإستنتاج: المسكنات الأفيونية مثل (تر امادول هيدروكلوريد) عندإعطائه بالجر عة العلاجية لفترة طويلة فإنه يؤدى إلى تأثير ضار ملحوظ على القشرة الدماغية ومع ذلك فقد أدى سحب المو اد الأفيونية إلى تحسن و التقليل الى حد ما من آثار ها الضنارة. 